\title{
Pengunaan Bilik Swab Pencegah Risiko Penularan Penyakit Infeksius di RS TNI AD Palangka Raya
}

\author{
Ervi Audina Munthe, Silvani Permatasari*, Agnes Immanuela Toemon, Lia Sasmithae \\ Program Studi Pendidikan Dokter, Fakultas Kedokteran UPR \\ *Penulis Korespondensi : silvani.permatasari@med.upr.ac.id
}

\begin{abstract}
Abstrak
WHO merekomendasikan pengambilan spesimen untuk diagnosis COVID-19 pada dua lokasi, yaitu dari saluran napas atas (swab nasofaring atau orofaring) atau saluran napas bawah [sputum, bronchoalveolar lavage, atau aspirat endotrakeal]. Tenaga medis harus memperhatikan keselamatan kerja dengan menggunakan APD (alat pelindung diri) yang tepat karena adanya kontak langsung dengan pasien terduga COVID-19 ketika mengambil sampel yang berisiko tinggi terinfeksi. Kasus COVID-19 di Indonesia meningkat setiap hari dan harga APD melambung tinggi dan terjadi kelangkaan. Mencermati kejadian tersebut maka sebagai wujud implementasi Tri Dharma Perguruan Tinggi, dosen UPR mengambil peran aktif dalam pengabdian masyarakat melalui program dosen pendukung SDM unggul untuk memberikan bilik swab dalam melindungi tenaga medis dari penyebaran infeksi secara langsung. Target dalam pelaksanaan pengabdian masyarakat ini adalah RS TNI-AD Palangka Raya. Metode yang digunakan adalah metode serah-terima alat dan demonstrasi pemakaian sebagai solusi kepada mitra yaitu RS TNI-AD Palangka Raya. Kesimpulan dari program pengabdian ini dengan adanya pemanfaatan bilik swab di RS dapat meminimalisir paparan penyebaran infeksi secara langsung ke tenaga medis serta sebagai alternatif saat krisis kelangkaan APD level 3.
\end{abstract}

Kata kunci: COVID-19, APD, Bilik swab, infeksi, tenaga medis

\section{PENDAHULUAN}

Penyakit Infeksi Emerging (PIE) adalah penyakit yang muncul dan menyerang suatu populasi untuk pertama kalinya, atau telah ada sebelumnya namun meningkat dengan sangat cepat, baik dalam hal jumlah kasus baru didalam suatu populasi, atau penyebaranya ke daerah geografis yang baru. Adapun beberapa penyakit infeksi emerging adalah flu burung (H7N9), SARS dan Coronavirus Disease (COVID-19) (Kemenkes, 2020a). Coronavirus Disease (COVID-19) yang disebabkan oleh virus Severe Acute Respiratory Syndrome Coronavirus-2 (SARS-CoV-2) (Kemenkes, 2020b).

Berdasarkan berbagai penelitian ilmiah, COVID-19 ditularkan melalui kontak erat dan droplet, kecuali jika ada tindakan medis yang memicu terjadinya aerosol (seperti bronkoskopi, nebulisasi dan lain lain) dimana dapat memicu terjadinya risiko penularan melalui airborne Adityo dkk, 2020).
Petugas kesehatan yang kontak langsung dengan pasien COVID-19 seperti yang mengambil sampel berisiko mudah terinfeksi. Tenaga medis dapat melindungi diri dengan mematuhi praktik pencegahan dan pengendalian infeksi, yang mencakup pengendalian administratif, lingkungan dan engineering serta penggunaan Alat Pelindung Diri (APD) yang tepat. Adapun kasus COVID-19 di Indonesia meningkat setiap hari, menyebabkan kebutuhan APD meningkat, sehingga terjadi kelangkaan APD dan harga APD mahal.

Melihat kejadian tersebut maka perlu diadakannya bilik swab yang dapat berkontribusi sebagai alternatif kelangkaan APD dan menjamin keamanan tenaga medis. Konsep program dosen pendukung SDM unggul adalah serah terima bilik swab dan mendemonstrasikan penggunaan bilik swab di RS TNI-AD Palangka Raya yang berlokasi di Jl. Diponegoro No. 55, Kota Palangka Raya. 


\section{METODE PELAKSANAAN}

Adapun metode pelaksanaan kegiatan ini menggunakan metode serah-terima alat dan demonstrasi pemakaian. Tahapannya adalah sebagai berikut :

a. Tahap Persiapan

Pada tahap ini tim pengusul melakukan observasi terhadap masalah sejauh mana yang ada dilapangan. Hal ini dilakukan untuk mengetahui kondisi Rumah Sakit TNI - AD Palangka Raya dan masalah yang dialami. Pada tahap ini juga tim pengusul menyiapkan bilik swab dan petunjuk teknis penggunaan bilik swab. Adapun persiapan bilik swab ini ini dilengkapi oleh lampu led, , exhaust fan, gloves, lampu UV sterilisator dan air purifier dengan hepa filter sehingga menjamin keamanan dari mikroorganisme di dalam bilik (Gambar 1). Sehingga bilik swab ini dapat berkontribusi dalam kelangkaan APD karena dapat menjadi perangkat yang digunakan sebagai penghalang terhadap penetrasi zat, partikel padat, cair, atau udara untuk melindungi tenaga medis dari cedera atau penyebaran infeksi atau penyakit secara langsung. Bilik swab ini dibuat senyaman mungkin untuk menjamin kenyamana dan keamanan dari tenaga medis yang bekerja mengambil spesimen pada pasien.

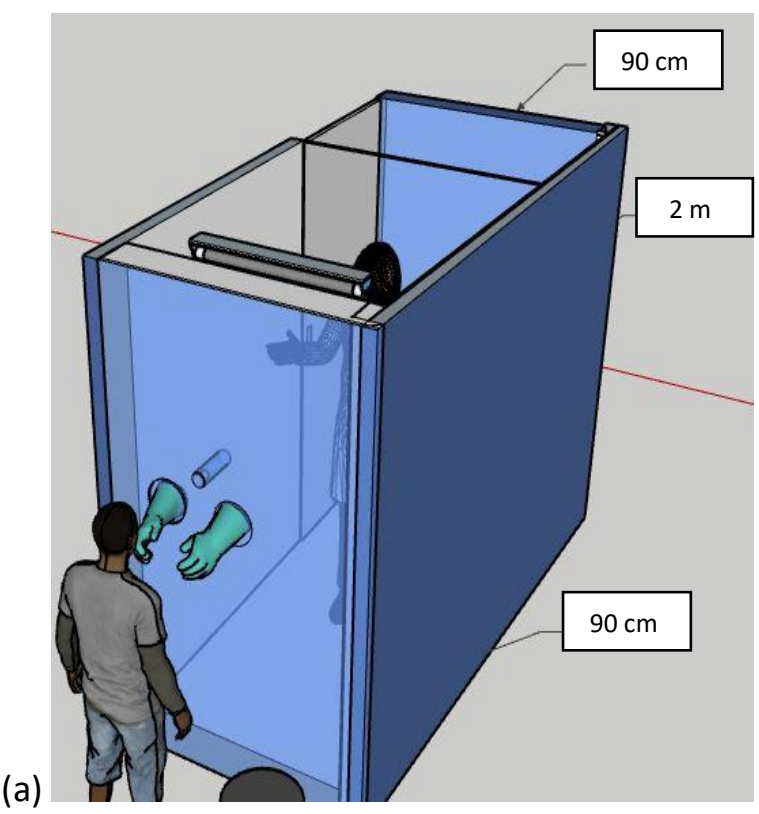

(b)

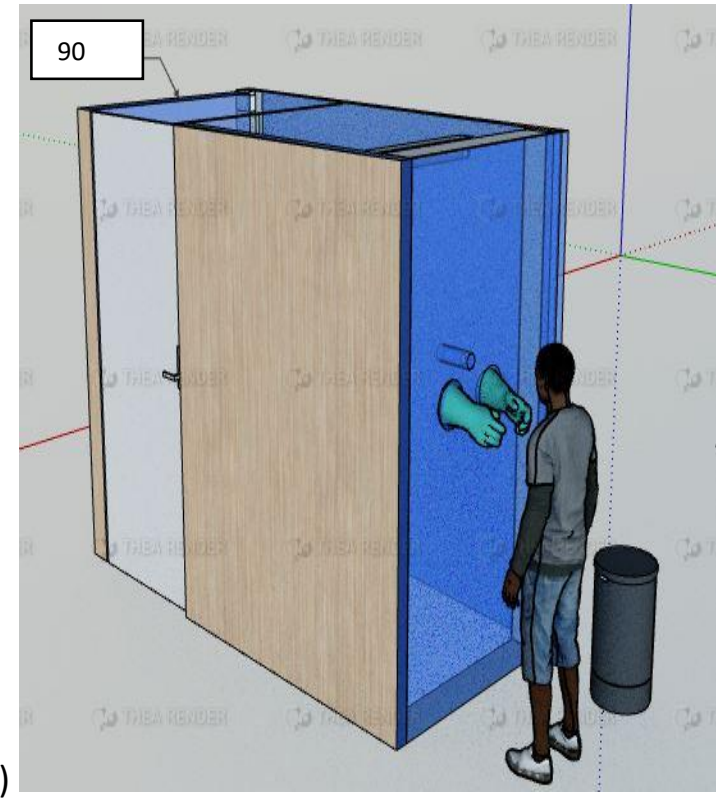

Gambar 1. (a) Bilik Swab Tampak Depan, (b) Bilik Swab Tampak Samping

b. Tahap Pelaksanaan

Pada tahap ini dilakukan serahterima bilik swab dan mendemonstrasi penggunaan bilik swab serta menjelaskan SOP penggunaan bilik swab kepada pihak manajemen dan tenaga medis yang ditunjuk dalam pengambilan spesimen.

c. Tahap Evaluasi

Pada tahap ini dilakukan evaluasi terhadap produk dan petunjuk teknis penggunaan serta evaluasi terhadap tahap-tahap kegiatan yang telah dilakukan.

\section{HASIL DAN PEMBAHASAN}

Serah terima bilik swab dan demonstrasi penggunaan bilik swab berupa penjelasan SOP penggunaan kepada pihak manajemen dan tenaga medis yang ditunjuk dalam pengambilan spesimen seperti dokter penyakit dalam dan analis kesehatan laboratorium RS TNI-AD Palangka Raya. Ide pemberian bilik swab ini adalah modifikasi 
dari bilik swab yang pernah diciptakan juga oleh Negara Korea serta dosen salah satu universitas di Kota Surabaya. Pembuatannya adalah hasil diskusi tim dosen dengan mengikuti standar yang sudah ada dengan dimodifikasi adanya roda pada bilik sehingga mudah dipindahtempatkan sesuai kebutuhan dan dipastikan juga dengan memberikan dan menjelaskan kelengkapan SOP untuk tahapan sebelum dan sesudah pengerjaan bagi tenaga medis di RS.

Bilik steril digunakan untuk pengaman tenaga medis saat mengambil sampel infeksius dari pasien, khususnya sampel infeksius dari tenggorokan atau nasofaring. Prinsip yang harus dipenuhi dari bilik swab ini antara lain harus dapat memberikan perlindungan terhadap bahaya yang spesifik atau bahaya-bahaya yang dihadapi (percikan, kontak langsung maupun tidak langsung), membantu memudahkan dan tidak menyebabkan rasa ketidaknyamanan yang berlebihan. dapat dipakai secara fleksibel, tidak menimbulkan bahaya tambahan, tidak mudak rusak, pemeliharaan mudah, dan diharapkan tidak membatasi gerak.

Di bilik ini yang diperbolehkan masuk hanyalah petugas, untuk mengambil spesimen dari pasien yang berada di luar bilik, disediakan sarung tangan yang menempel pada bilik. Selain itu juga untuk menambah keamanan agar membunuh mikroorganisme di dalam bilik juga disediakan lampu UV sterilisator dan air purifier dengan hepa filter. Prinsip dari bilik swab ini adalah bilik kerja steril yang dapat bekerja dengan pengaturan dengan membuat ruangan bertekanan positif, maka jika di luar ada droplet atau kontaminan dari pasien maka tenaga medis akan tetap terlindungi sehingga petugas tidak perlu memakai APD level 3 sehingga sesuai konsepnya alat ini dapat menghemat APD. Sementara untuk pasien perlu disiapkan tindakan desinfeksi sehingga pasien tetap aman.

Adapun petunjuk atau standar operasional prosedur (SOP) penggunaan bilik swab ini adalah:
A. Sebelum menggunakan bilik swab yaitu:

1. Melakukan persiapan alat bahan untuk swab oro dan nasofaring

2. Menyambungkan kabel listrik bilik swab pada sumber listrik

3. Memposisikan bilik swab dan mengunci roda bilik swab

4. Menghidupkan lampu UV untuk sterilisasi bilik swab selama 30 menit

5. satu orang swabber menggunakan apd level 2

6. satu orang handling menggunakan apd level 3

7. Mematikan lampu UV sebelum menggunakan bilik swab

8. Menyalakan lampu, exhaust fan dan air purifier dengan hepa filter

B. Saat menggunakan bilik swab yaitu:

1. Swabber masuk kedalam bilik swab sebagai operator.

2. Tim handling membantu kerja operator dengan mengarahkan pasien serta membantu pengambilan spesimen dari luar bilik swab.

3. Bila pasien, operator dan tim handling telah siap maka tindakan pengambilan swab oro dan nasofaring dapat dilakukan.

4. Apabila memungkinkan selama penggunaannya area kaca bilik swab dapat dilakukan disinfeksi pada perpindahan tiap pasiennya.

C. Setelah selesai menggunakan bilik swab yaitu:

1. Membersihkan kaca bilik swab dengan disinfeksi

2. Mematikan lampu, exhaust fan dan hepa filter

3. Mensterilisasi bilik swab dengan menghidupkan lampu UV selama 30 menit

Mematikan lampu UV setelah digunakan 


\section{KESIMPULAN DAN SARAN}

Setiap tahap kegiatan pengabdian masyarakat ini berjalan dengan lancar. Bilik swab ini dapat berkontribusi dalam kelangkaan APD karena dapat menjadi perangkat yang digunakan sebagai penghalang terhadap droplet atau penetrasi zat padat, cair, dan gas untuk melindungi tenaga medis dari penyebaran infeksi secara langsung. Bilik swab ini menjamin kenyamanan dan keamanan dari tenaga medis yang bekerja mengambil spesimen pada pasien.

Selanjutnya dapat melakukan kegiatan pengabdian masyarakat perlu dibuat produk bilik swab di RS rujukan covid lainnya yang menangani pengambilan swab masal ke pasien suspek COVID-19 serta melakukan penyuluhan cara penggunaan APD yang tepat kepada tenaga medis.

\section{DAFTAR PUSTAKA}

Adityo, S., R. C. Martin, P. Ceva, 2020. Coronavirus Disease 2019: Tinjauan Literatur Terkini. Jurnal Penyakit Dalam Indonesia. Vol 7, No.1. Maret 2020.

Kemenkes. Pedoman Teknis Bangunan Dan Prasarana Ruang Isolasi Penyakit Infeksi Emerging (PIE). 2020

Kemenkes. Petunjuk Teknis Alat Pelindung Diri (APD) dalam Menghadapi Wabah COVID-19. 2020

\section{FOTO KEGIATAN}
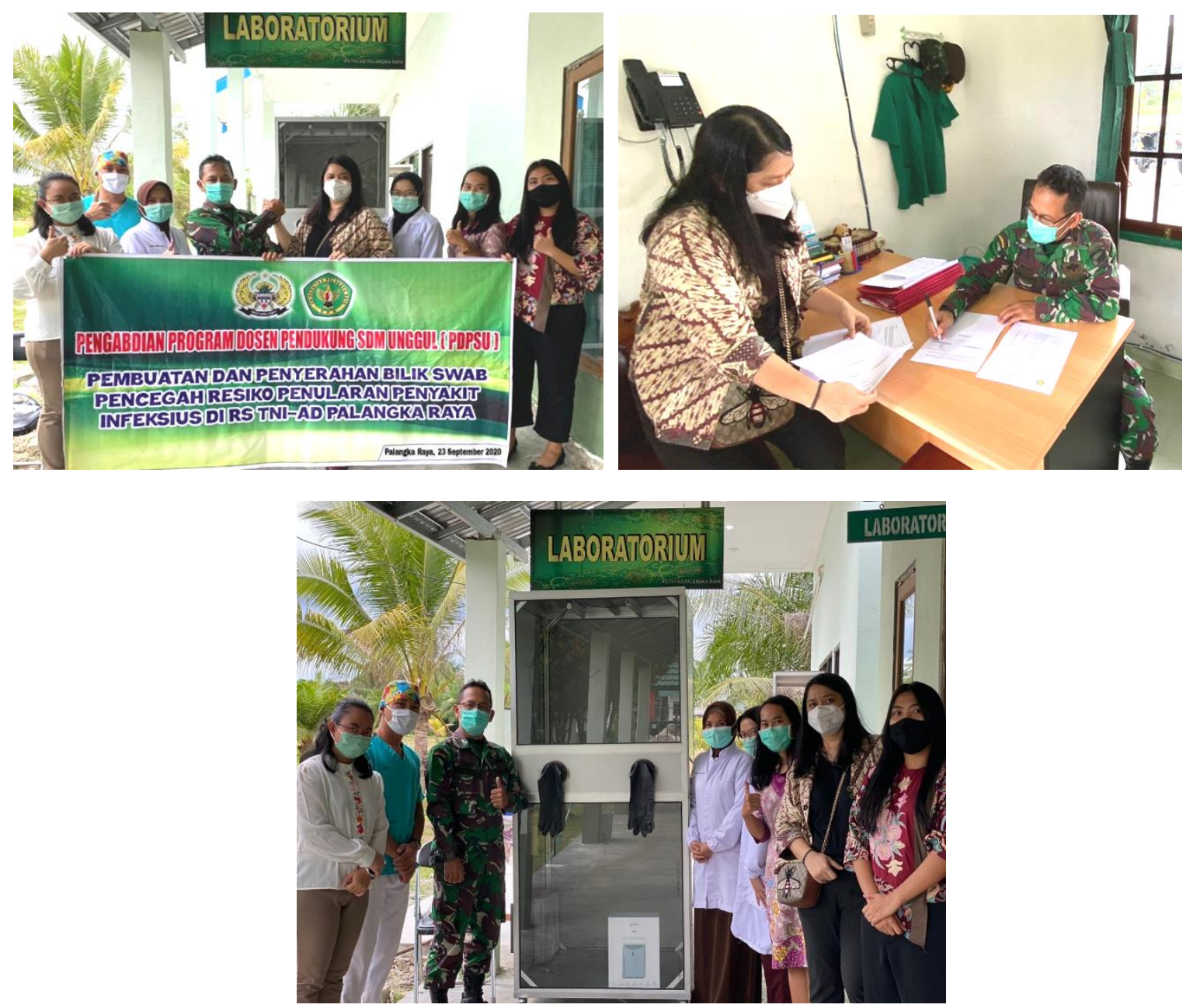

Kegiatan penyerahan bilik swab di depan laboratorium RS TNI-AD Palangka Raya 